\title{
Fıkhî Eleştiri Bağlamında İbn Abdülber’in Zâhirîleri Eleștirisi*
}

\section{Ibn Abd al-Barr's Criticism of the Zāhirīs in the Context of Fiqhi Criticism}

\author{
Rifat Yildiz ${ }^{\text {a, ** }}$ \\ ${ }^{a}$ Dr. Öğr. Üyesi, Muş Alparslan Üniversitesi, İslami İlimler Fakültesi, Temel İslam Bilimleri Bölümü, İslam Hukuku Anabilim Dalı, 49250, \\ Muş/Türkiye. \\ ORCID: 0000-0002-3126-7854
}

\section{MAKALE BİLGİSİ}

\section{Makale Geçmişi:}

Başvuru tarihi: 30 Mart 2021

Düzeltme tarihi: 10 Mayıs 2021

Kabul tarihi: 20 Mayıs 2021

\section{Anahtar Kelimeler:}

İslam Hukuku,

Eleştiri,

Zâhirîlik,

Usûl,

Füru'.

\section{ART ICLE INFO}

\section{Article history:}

Received: 30 March 2021

Received in revised form: 10 May 2021

Accepted: 20 May 2021

\section{Keywords:}

Islamic Law,

Criticism,

The Zāhirī Madhhab,

Usool,

Furu'al Fiqh.
ÖZ

Günümüzde İslam hukuku alanında ortaya çıkan yeni meselelere çözüm üretmeye çalışılırken geçmiș dönemde yaşamıs âlimlerin meseleleri değerlendirme yöntemlerinin tespiti ve sahih fikhî bir çözüme ulaşmak için sarf ettikleri çabaların bilinmesi önemlidir. Bu bağlamda, XI. yüzyılın önemli âlimlerinden biri kabul edilen İbn Abdülber'in (v. 463/1071) Zâhirîlere yönelik eleştirisi önem arz etmektedir. Bu eleştirilerin odağındaki meseleler ve usûlî dayanaklarının tespiti, İbn Abdülber tarafından yazılmıs eserler, Zâhirîlerin kaynakları ve konuyla ilgili yapılmıs çalısmalara dayanacaktır. İbn Abdülber'in eleştirileri bağlamında Zâhirîlerle olan görüş farklılıkları ve bunların dayandıkları usûlî esaslar incelenecek, bu konuda farklı hüküm verme nedenleri ortaya konulmaya çalışılacak ve bu hükümlere varırken izlemiş oldukları yöntemler saptanacaktır.

\section{A B S T R AC T}

While trying to find solutions to new issues that arise in the field of Islamic law today, it is important to determine the methods the past ulema based upon in evaluating the fiqhi issues to reach a sahih fiqhi solution. The criticism of Ibn Abd al-Barr (d. 463/1071), who is accepted as one of the outstanding ulema of the XIth century, of the Zāhirīs is important. In the context of Ibn Abd alBarr's criticism, the differences of opinion with the Z̄âhirīs and the usuli principles on which they are based will be analyzed, the reasons for making different ahkam on this issue will be put forward and the methods they followed while reaching these ahkam will be determined.

\section{Giriş}

F1kıh ilmiyle uğraşan fakihler sahâbe döneminden beri naslar çerçevesinde Müslümanların meselelerine çözüm üretmeye çalışmışlardır. Bu amaçla birçok çalışma yapılmış konuyla ilgili birçok eser kaleme alınmıştır. İslam Hukukuyla ilgili çaba sarfeden fakihlerin aldıkları eğitim, ders aldıkları hocaların etkisi, fikhî kabiliyetleri ve yaşadıkları toplumun örf ve adetleri çalışmalarına etkide bulunmuştur. Ayrıca şer'i nasları anlama ve kavrama güçlerinin farklılı̆̆ı, meselelerle ilgili âyet ve hadislere vukûfiyet, önceki fakihlerin konularla ilgili icmâ' ve ihtilâflarını bilmek de onların farklı görüş belirtmelerine neden olmuştur.

\footnotetext{
* Bu çalışma, 7 Aralık 2020 tarihinde Muş Alparslan Üniversitesi İslami İlimler Fakültesinde düzenlenen İslam Düşüncesinde Eleştiri Kültürü ve Tahammül Ahlâkı II (Klasik Dönem- M. VII.- XII. Yüzyıllar) Sempozyumunda sunulan bildirinin geliştirilmiş halidir.

** Sorumlu yazar/Corresponding author. e-posta: r.yildiz@alparslan.edu.tr
} 
Yukarıda saydığımız gerekçelerden dolayı aynı meseleyle ilgili fakihlerce ulaşılan farklı fikhî sonuçlar bazen eleştiri konusu olmuştur. Peygamberler dışındaki insanların masum olmaması nedeniyle ulaşmış oldukları fikhî sonuçların yanlış olma ihtimali bulunduğundan hiçbir fakih vermiş olduğu hükmün veya fetvanın kesin ve tek doğru olduğunu iddia etmemiştir. $\mathrm{Bu}$ nedenle fakihlerin ictihâtlarıyla ulaştıkları sonuçlar zanna dayalı olduğundan bu hükümlerin doğru olma ihtimali bulunduğu gibi yanlış olma ihtimali de bulunmaktadır. $\mathrm{Bu}$ nedenle fakihler daha doğruya ulaşmak ve yanlışlardan kurtulabilmek için yanlış gördüklerini, delillere dayalı olarak eleştirdikleri gibi kendileri de eleştiriye açık olmuşlardır. Bu anlayışı bütün İslamî ilimler sahasında görmek mümkündür.

Günümüzde İslam hukuku alanında ortaya çıkan yeni meselelere çözüm üretirken geçmiş âlimlerin meseleleri çözme yöntemlerinin öğrenilmesi/bilinmesi ve sahih fikhî bir çözüme ulaşmak için sarf ettikleri çabaların bilinmesi önemlidir. İbn Abdülber, Mâlikî mezhebine mensup bir fakih olmasına rağmen fikhî konuları incelerken objektif bir gözle meselelere yaklaşmakta ve taassuptan uzak bir anlayışla görüşlerini ifade etmektedir. Nitekim fikhî meseleleri açıklarken bazen kendi mezhebinde benimsenen görüşlere ters düşen görüşler ileri sürebilmekte, diğer fikıh mezheplerinin ictihadlarını da destekleyebilmektedir. Bu nedenle XI. Yüzyılın önemli âlimlerinden biri kabul edilen İbn Abdülber'in Zâhirîlere yönelttiği eleştirilerin bilinmesinin fikhî formasyonun kazanılması açısından önemli olduğu söylenebilir.

$\mathrm{Bu}$ çalışmada İbn Abdülber'in Zâhirîlere yönelttiği eleştirilerin odağında bulunan kıyas ve berâet-i zimmet gibi usûli konularla bunlara dayalı olarak füru' fikıhla ilgili ulaşılan farklı görüşlerin tespiti, İbn Abdülber tarafından yazılmış eserler, Zâhirîlerin kaynakları ve konuyla ilgili yapılmış çalışmalara dayanacaktır. $\mathrm{Bu}$ çalışmada İbn Abdülber'in eleştirileri bağlamında Zâhirîlerle olan görüş farklılıkları ve bunların dayandıkları usûlî esaslar incelenecek, bu konuda farklı hüküm verme nedenleri ortaya konulacak ve bu hükümlere varırken izlemiş oldukları yöntemler tespit edilmeye çalışılacaktır.

\section{2. İbn Abdülber ve Zâhirîlik}

İbn Abdülber'in Zâhirilere yönelik eleştirilerine geçmeden önce konuya hazırlık amacıyla ve konunun sağlıklı bir şekilde anlaşılması için İbn Abdülber ve Zâhirîlik hakkında k1saca bilgi vermek uygun olacaktır.

\section{1. İbn Abdülber'in Hayatı}

İbn Abdülber, Endülüs'ün Kurtuba şehrinde 368/978 y1lında dünyaya gelmiştir. İbn Abdülber'in dünyaya geldiği ve çocukluğunu yaşadığı zamanlarda Endülüs en parlak dönemlerini yaşamaktaydı. İbn Abdülber'in yaşadığı sonraki dönem ise Endülüs'ün sıkıntılar ve iç çekişmeler içinde istikrarsızlaşmaya doğru gittiği bir dönemdir. Bu dönem Endülüs Emevî Devletinin son dönemiyle Mülûku’t-Tavaif dönemini içine almaktadır (İbn Abdüber, ts: 3/1128).

İbn Abdülber'in eser verdiği alanlara baktığımızda çok yönlü ilim adamı olduğunu görülür. Hadiste otorite olduğu gibi, fikıhta da yaşadığı dönemde zirvede yer almakta aynı zamanda tarih ve nesep ilminde sözüne itibar edilen âlim konumundaydı. Hadîs ilmini, hocası Abbas b. Asbağ el-
Hemedânî'den (v. 386/996), nahiv ilmini Abdulaziz b. Ahmed el-Ehfeş’ten (v. ?), fikıh ilmini İbn Mekvî diye tanınan Ahmed b. Abdülmelik el-İşbilî’den (v. 401/1010) alır. İbn Faradî'nin (v. 403/1012) ders halkasına devam eder, yine hadis ve rical ilminde başka birçok hocadan faydalanır. Bu hocaları; Abdulvâris b. Süfyân (v. 395/1005), Halef b. elKasım (v. 393/1002), Ahmed b. Kasım et-Tahertî (v. 395/1004), Halef b. Saîd'dir (v. 403/1012) (Mahlûf, 2003: 1/176; Sallabî, 2011: 27).

İbn Abdülber, ilim öğrenmek maksadıyla Endülüs dışına çıkmamasına rağmen 100’ü Endülüslü olan 107 âlimden birçok ilim dalıyla ilgili icazet almıştır. İbn Abdülber farlı yerlerden yanına ilim öğrenimi için gelen öğrenciler ve değişik vesilelerle karşılaştığı âlimler vasıtasıyla geldikleri beldelerin ilmî birikiminden haberdar olmuştur. İbn Abdülber, Ebû Dâvûd'a (v. 275/889) ait es-Sünen'e arada sadece iki ravi ile ulaşarak bu eserin âli isnadına sahip olmuştur. Ayrıca İbn Abdülber, İmam Mâlik'in (v. 179/795) el-Muvatta'ına “es-Senedü'l-Endelüsî” denilen Abdülvâris b. Süfyan-Kâsım b. Asbağ (v. 340/951) -Muhammed b. Vaddâh (v. 287/900) -Yahyâ b. Yahyâ (v. 234/849) senediyle ulaşmıştır. İslamî ilimlerin yanı sıra coğrafya, tıp, matematik, astroloji gibi bilim alanlarında da mesai harcamış, icâzet yolu ile birçok eserin rivayet hakkını elde ederek öğrencilerine okutmuştur (Câsim, 1999: 269). İbn Abdülber bu eğitim faaliyetleri sonucunda kendisinden sonra birçok ilimde otorite olarak kabul edilebilecek âlim de yetiştirmiştir. Bunlardan biri de İbn Hazm'dır (v. 456/1064). İbn Hazm, her ne kadar İbn Abdülber'le akran olsa da kendi eserlerinde ondan istifade ettiğini, ondan hadis dinlediğini ve kendisine rivayet için izin verdiğini söylemiştir (İbn Hazm, 2004: 318).

İbn Abdülber, bir süreliğine kendisine resmi olarak yarg1 tecrübesini kazandıran Üşbûne ve Şenterîn kadılık görevlerini yerine getirir. Bu arada "el-Kâfi” adlı eserini sözkonusu dönemde yazar. Bahsi geçen eserini Malikî mezhebinin görüşleri doğrultusunda fetva kitabı formatında telif eder (Câsim, 1999: 269).

İbn Abdülber hayatının çoğunu Kurtuba'da geçirir (İbn Ferhun, ts: 2/367; Sercânî, ts: 368) fakat iç karışıklıkların yaratmış olduğu kargaşa ortamından dolayı sonraları Kurtuba'dan ayrılarak Endülüs'ün batısında bulunan Dâniye, Belensiye ve Şâtibe gibi şehirlerde hayatını sürdürür (İbn Kesîr, 2010: 428; İbn Bessâm. 1997: 1/615-616) Şâtibe'ye yerleşen İbn Abdülber hayatının geri kalan kısmını, Şâtibe'de "Bustânü İbn Abdülber" diye anılan bahçeli evinde ilim ve telif faaliyetleri ile geçirir ve 463/1071 yılında Şâtibe'de vefat eder (İbn Ferhun, ts: 2/369; Zehebî, ts: $3 / 1131$ ).

Bazı kaynaklarda, ilk dönemlerde Zâhirî mezhebine meyilli iken daha sonraları Mâlikî mezhebine geçtiği ile ilgili kayıtlar bulunmaktadır (Zehebî, 1417/1996: 19/157; Câsim, 1999: 269). Zâhirîlerin kıyasa muhalefetlerini eleştirmesi ve Zâhirîlerin kabul etmediği istihsan ve Medine amelini, fikhî tercihlerinde delil olarak kullanmış olması, Zâhirî olmadığının bariz bir kanıtıdır. Her ne kadar Mâlikî usulüne ve prensiplerine bağlılığı bilinse de bazı tabâkat yazarları onu ictihâd derecesine ulaşmış müctehid bir âlim olarak nitelemiştir (Zehebî, 1417/1996: 19/157). 


\section{2. İbn Abdülber'in Eleştiri Anlayış1}

İbn Abdülber'in gerek naslardan hüküm çıkarırken veya fikhî tercihlerde bulunurken Mâlikî fakihlerin dayandığı delil ve yöntemlerden faydalanması gerekse de kendini Mâlikî mezhebine izafesi onun Mâlikî ekolüne mensup bir fakih olduğunu rahatlıkla söyleyebiliriz. Mâlikî mezhebine mensup olması onun mezhebin bütün görüşlerini sorgulamadan kabul ettiği anlamına gelmemektedir. Eserleri incelendiğinde, takip ettiği usûl anlayışı ve riayet ettiği fikhî prensiplere uymayan görüş kimden gelirse gelsin onu eleştirdiği ve kendi fikhî kaidelerine göre doğru olan görüşü açık bir şekilde desteklediği görülür. $\mathrm{Bu}$ nedenle yapmış olduğu eleştirilerden diğer mezhep âlimleri nasiplerini aldıkları gibi bazen de mensubu bulunduğu Mâlikî fakihleri de eleştirilmekten kurtulamamıştır. Bu özelliğinden dolayı bazıları onun Şâfiî mezhebine meyilli olabileceğini ifade etmişlerdir (Humeydî, 2008: 544). Nitekim İbn Abdülber, ilmî donanımı, fikhî kişiliği ve dini hassasiyetinden dolayı insanlar ve onların görüşleri hakkında taassuba düşmeden hakkaniyet üzere hareket ederek, insaflı olmaya çalışmıştır. $\mathrm{Bu}$ özelliğine bir örnek olarak bazı hadis ehlinin Ebû Hanife'yi (v. 150/767) eleştirilerinde Ebû Hanife'yi savunarak onlara şöyle cevap vermiştir: "Hadis ehli Ebû Hanife'yi eleştirirken aşırı gitmişler ve haddi aşmışlardır." (İbn Abdülber, 1994; 1080; Karadağ, 2020: 36-37) Eserlerinde bu tür değerlendirmelere pek çok yerde rastlamak mümkündür.

İbn Abdülber, kişilik olarak ilmî bağımsızlığa önem veren, taklitten hoşlanmayan ve fikrî donukluktan uzaklaşmak için aslî kaynaklara dayanarak yeni ictihâtlarda bulunmayı teşvik eden bir âlimdi. O dönem Endülüs'te bulunan yerleşik anlayış olan sadece füru' fikıhla uğraşmayı yeterli gören âlimlerin aksine fakih ve muhaddislerin yöntemlerinden istifade ederek yeni bir anlayışla fikhî meseleleri ele almıştır. Eserlerinde fikhî konularda hiçbir mezhebî taassup göstermeden yanlış gördüğü görüşleri eleştirdiği ve doğru bildiği görüşleri de takdir ettiği pek çok husus bulunmaktadır. Konuya açıklık getirmek için bunlardan bazıları şöylece zikredilebilir:

\subsubsection{Mâlikî Mezhebinin Bazı Görüşlerine Yönelik Eleştiri Örneği}

Abdest konusunu işlerken Mâlikî mezhebinde yabancı kadına dokunmayla abdestin bozulup bozulmayacağ 1 hususuyla ilgili leh ve aleyhteki delilleri inceledikten sonra şöyle demektedir: "Mezhebimize bağlı arkadaşlar, arada ince bir örtü varken, nikâhlanabilen bay ve bayanların birbirine dokunmasıyla, abdest alınması gerektiği yönünde görüş belirtmektedirler. Çünkü bu durumda yani ince bir örtünün olması esnasında şehevî lezzet devam etmektedir ki bundan dolayı abdestleri bozulur. Ancak âlimlerin çoğunluğu, onlara bu konuda muhalefet etmektedirler ve bana göre de bu muhalefet doğrudur. Çünkü tene dokunmaksızın oluşan lezzetin abdest alınmasını gerektirmediği ile ilgili icmâ vardır. Aynı şekilde mezhebimize mensup arkadaşlarımıza göre de lezzet olmaksızın oluşan dokunmadan dolayı abdest alınmasına gerek yoktur." (İbn Abdülber, 1414/1993: 3/57). Nitekim konuyla ilgili cumhurun dayandığı deliller ve meseleyle ilgili ifade ettikleri görüşlerin uygun olduğu anlaşılmaktadır. Zira hiçbir fakih, yabancı karşıt cinslerin teninin biri birine teması olmadan, elbiselerin temasıyla abdestin bozulacağıyla ilgili fikhî bir görüş belirtmemiştir.
Ayrıca abdestin bozulmasına; şehvet hissi gerekçe olarak ileri sürülürse, o durumda şehvet hissi veren bütün düşünce ve davranış sonucu abdestin bozulması gerekir. Böyle bir iddiayı da hiçbir fakih ileri sürmemiştir.

\subsubsection{Hanefi Mezhebinin Bazı Görüşlerine Yönelik Eleştiri Örneği}

İbn Abdülber vitir namazını ele aldığı bölümde bir takım konuları açıklığa kavuşturmak amacıyla mesele ile ilgili birçok delil zikreder. Daha sonra Mâlikî ve Hanefî âlimlerin, vitir namazının rekâtları ve Hanefîlerin vitir namazının vacip oluşuna dair görüşlerine (Şeybânî, ts: 1/190-193) dayanak olarak öne sürdükleri hadisleri aktarır ve şöyle der: "Muhammed b. Sîrîn (v. 110/729), İbn Ömer'den şöyle rivayette bulunmuştur: Resulullah (s.a.s) buyurdu ki: "Akşam namazı gündüzün vitridir ve siz de gecenin sonundaki namazı vitir yapın. Mâlikîler ve Hanefîler bu hadisi kendi görüşleri için delil olarak ileri sürüyorlar fakat bu hadiste iki grup için de açık bir delil bulunmamaktadır." (Şeybânî, ts: 1/190-193).

Vitir namazının sünnet olduğu kanaatinde olan İbn Abdülber, vitrin sünnet oluşu ile ilgi delilleri sunduktan sonra vitri vacip olarak gören Hanefîlerin görüşünü eleştirirken de şöyle demektedir: "Farzlar ancak kesin delillerle sabit olurlar ki bunda ihtilaf yoktur. Vitir sünnettir, vacip değildir sözünde (bu konudaki şaz görüş olmasaydı) nerdeyse icmâ oluşacaktı." (İbn Abdülber, 1414/1993: $5 / 267)$.

Ona göre vitrin tekli rekâtla kılınması gerektiğini ifade eden hadis, vitrin vacip olmasına ve tek selamla kılınması hususuna delil olamaz. Bu tür hükümler ancak kesin delillerle tespit edilebilirler. Yukarıda rivayet edilen hadiste bu yönde net bir ifade bulunmaktadır. Bu nedenle vitir namazı sünnet olan ve birden fazla selamla kılınabilen bir namazdır (İbn Abdülber, 1414/1993: 5/267).

\subsection{3. Şâfî̀ Mezhebinin Bazı Görüşlerine Yönelik Eleştiri Örneği}

Şafîi (v. 204/820) mezhebine göre namaz kılarken teşehhütte, tahiyyattan sonra salâvat getirmek farzdır (Şafiî, ts: 91; Müzennî, 1419/1998: 21). Şâfîler'in bu görüşünü uygun görmeyen İbn Abdülber, Resulullah'a (s.a.s) salâvat getirme konusunda bulunan deliller başlığında meseleyi detaylı bir şekilde ele alır. Delilleri değerlendirdikten sonra salâvatın son teşehhütte farz olduğunu söyleyen İmam Şâfî̀'ye şöyle bir eleştiri getirir: "Asıl olan farzların, kendisine muarız olmayan deliller veya muhalefetin söz konusu olmadığı icmâ' ile sabit olmuş olmasıdır. $\mathrm{Bu}$ konudaki İmam Şâfî̀'nin ve arkadaşlarının görüşü zayıftır. Ben, her namazda Peygamber'e (s.a.s) salâvat getirmeyi zorunlu görmüyorum; ama salâvatı terk etmeyi de hoş bulmuyorum." (İbn Abdülber, 1414/1993: 6/261)

Ayrıca İbn Abdülber, füru' meseleler dışında bazen usûl kaideleri hususunda da fakihlere eleştirilerde bulunur. $\mathrm{Bu}$ konuda sedd-i zerâi' ${ }^{i}$ reddeden Şâfîilerin dayandıkları delilleri şu şekilde nakletmektedir: Şâfîlerden bir grup "Resulullah (s.a.s): Kötü zandan sakınınız. Zira kötü zan, sözlerin en yalanıdır." (Mâlik b. Enes, 1425/2004: 1327; Buhârî, 1407/1987; 2253; Müslim ts: 1985) hadisi ve benzerlerini delil getirerek alışveriş konusunda zerâi' delilini reddetmeye çalışmışlardır. Reddedenler bu konuda şunları 
söylemişlerdir: Allah (c.c) "Şüphesiz zan, haktan (ilimden) hiçbir şeyin yerini tutmaz." Resulullah (s.a.s) de "zandan sakının” demiştir. Şüphesiz zan sözlerin en yalanıdır. Ayrıca şunu da demiştir: "Şüphesiz Allah, müminlerin kanını, ırzını ve malını haram kılmıștır. Ve mümin hakkında da ancak hayır düşünülmesini istemiştir." Ayrıca Peygamber (s.a.s), şöyle buyurmuştur: "Zanda bulunduğunuz vakit o zannınızı gerçek gibi kabul etmeyiniz." Şâfiîler bu hadislere dayanarak şöyle demektedirler: Allah'ın koymuş olduğu hükümler gerçekler üzerine bina edilir zan üzerine değil. Bu ilke gereği Şâfiîler zerâi` delilini reddetme yoluna gitmişlerdir (Müzenî, 1419/1998: 78; Sübkî, ts: 10/159-160; Şirbînî, 1997/ 1418: 1/311).

İbn Abdülber, sedd-i zerâi` aleyhine görüş belirten Şâfiîlerin delillerini aktardıktan sonra, sedd-i zerâi'i delil olarak gören Mâlikî ve Hanefîlerin lehteki delillerine değinmekte ve senet yönünden konuyla ilgili aleyhteki hadisin sahih olmadığını ifade etmektedir (İbn Abdülber, 1967: 18/20-21). Sedd-i zerâi' ile ilgili dayanak olarak kabul edilen rivayetlerin; "Ömer (r.a) şöyle diyor: İyi bir at alıp, Allah rızası için birine verdim. Adam ata iyi bakmıyordu. Onun için atı satın almak istedim. Zannedersem ucuz da alabilecektim. Durumu Resullah'a (s.a.s) sordum. Resulullah (s.a.s) şöyle buyurdu: "Bir dirheme de verse alma. Çünkü verdiği sadakadan dönen kustuğunu yiyen köpek gibidir." (Mâlik b. Enes, 1406/1985: Zekat, 49; Müslim, 1412/1991: Hibat, 1) "Bir adam, Resulullah'a (s.a.s) sordu: 'Ey Allah'ın Resulü! Hanımım hayılı iken bana helal olan nedir?' Resulullah (s.a.s): 'Üzerine izarını bağlasın, izarın yukarısı için istediğinde serbestsin." (Mâlik b. Enes, 1406/1985: "et-Tahâre”, 93.) yorumunda İbn Abdülber, sedd-i zerâi' deliliyle ilgili şunları söylemektedir: Hz. Peygamber'in hayızlı kadına yaklaşma ile ilgili olarak söylediği sözü şu anlama gelmektedir: Bu hadis, hayızlı kadının erkeği ile mübaşereti esnasında belden aşağı kısmının, ihtiyaten ve "sedd-i zerâi"” deliline göre örtülü olmasını ifade etmektedir. Eğer kadının baldırına dokunmayı serbest bıraksaydı, bu durum icmâ' ile yasaklanmış olan kadının hayızlı yerine geçişe yol açacaktı. Bundan dolayı ihtiyaten bu bölgeye dokunmayı yasakladı. Aslında haram kilınan bölge eziyet yeridir ki Kur'ân'ın zahiri de bunu ifade etmektedir (İbn Abdülber, 1967: 3/174).

İbn Abdülber'in Zâhirîlere yönelik fikhî eleştirilerine geçmeden önce Zâhirîliğin ne olduğu, gelişimi ve temsilcileriyle ilgili kısa bir bilgi vermenin konunun anlaşılmasına katkı sunacağına inanıyoruz.

\subsection{Zâhirîlik}

Zuhûr mastarından türeyen ve ismi fail olan zâhir kelimesi, sözlükte "açık, ortaya çıkan, görünen, berrak, aşikâr olmuş, tezahür eden" anlamına gelmekte ve bir şeyin dış, görünen kısmını ifade etmektedir. Fıkıh usûlünde ise "hükmün konuluş gayesi" ya da "söylenen sözle kastedilen anlamı" ifade eden "mâna" karşıtı olarak kullanılmaktadır (Buhârî, A. 1418/1997: 1/72). Bu ifade şekliyle zâhir lafzı genel olarak ta'lîl, re'y ve kıyas karşıtlığı anlamlarına gelir. Zâhir sözcüğünün bu biçimiyle kullanımında, kelimelerin gerçek anlamlarının ve hükümlerin vaz' ediliş gayeleri üzerinde tefekkür etmeyen, sözün söyleniş gayesini göz önünde bulundurmadan nasları sadece ilk akla gelen ve anlaşılan zâhir anlamlarına uygun bir şekilde anlayan kişilere de zâhir ehli denir. Buna karşılık, lafızların manalarının tespit ve tatbikinde kanun koyucunun maksadını önemseyenlere ehl-i bâtın denilmemiş bu hususu/vasfi ifade için ehl-i re'y ifadesi kullanılmıştır (Apaydın, 2013:44/93).

Dinin temel metinleri olan hadis ve âyetlerin anlaşılmasında zâhir anlamın esas oluşu İslâm âlimlerinin çoğunluğunun genel görüşüdür. Bu prensibin manası ve gayesi, şeriatın esasını oluşturan hadis ve âyetlerin zâhir manalarını "anlamsızlaștıracak ve aşındıracak" bütün yorum şekillerinin önüne geçmektir. Dil bir iletişim ve anlaşma vasıtası olduğundan hadis ve âyet metinlerinin anlaşılmasında öncelikle zâhir anlam göz önünde bulundurulmalıdır. Nasları anlama ve kavrama sürecinde zâhir mananın dikkate alınması gerekli olduğundan ve doğal görüldüğünden bu anlayışa uygun davranan ve bunu savunan kişiler için "zâhirî" tabiri kullanılmamıştır. Yorum işlemini gerektirecek bir durum oluşmadıkça lafzın zâhir anlamından vazgeçilemeyeceği kuralı fıkıh usûlü ve fıkıh ilimlerinin yanı sıra kelâm ilminde de özellikle dikkate alınmaktadır (Teftâzânî, 1428/2007: 105). Temel olarak Zâhirîlik, re'yin fikıh ilminde ne derece yer alabileceği hususunda ortaya çıkan ihtilafta re'ye olan muhalefetin ulaştığı en uç anlayışı temsil eder.

Zâhirîlik anlayışının sistemli bir yapı oluşturması ilk defa Dâvûd b. Ali (v. 270/884) ile başladığı bilinse de bu düşüncenin örneklerini önceki dönemlerde de görmek mümkündür. $\mathrm{Bu}$ anlayışa, tâbiîn neslinde ve hatta bazı örnekleriyle sahâbîler arasında da yatkın olan kişileri görmek de mümkündür. Durum böyle olmasına rağmen Zâhirîlik düşüncesinin sistemli bir anlayış haline gelmesinin Dâvûd b. Ali ile başladığını söylemek isabetli olacaktır. Onun ilim halkasında yetişenlerin önde gelenlerinden biri oğlu Ebû Bekir Muhammed'dir (v. 297/910). Dâvûd'un öğrencileri arasında bulunan bir başka önemli fakih de Ebû Bekir Muhammed b. İshak el-Kâsânî'dir (v. 280/893). Dâvûd b. Ali'nin diğer bilinen öğrencileri Ebû Saîd Hasan b. Ubeyd en-Nehrebânî (v. ?) ve Niftaveyh (v. 323/935) ve Ebû İshak İbrahim b. Câbirdir (v. 310/922). Ayrıca İbnü'l-Mugallis'in (v. 324/936) Zâhirîlik düşüncesi açısından önemli bir yeri bulunmaktadır. Onun yetiştirdiği birçok öğrenci arasında bulunan Haydere b. Ömer ez-Zendeverdî (v. 358/968) ve Ali b. Muhammed el-Bağdâdî (v. ?) de Zâhirî düşüncenin ve anlayışın öğrenilmesi ve yayılmasında önemli katkıları olmuştur (Şirâzî, ts: 175-179).

Zâhirîlik özellikle Endülüs bölgesinde hayat bulmuş ve belli bir müddet burada etkili olmuştur. Zâhirî anlayışın Endülüs'teki en görkemli dönemi İbn Hazm'dan sonra olduğu bilinse de daha önce de Endülüs'te Zâhirîlik düşüncesini benimsemiş kimselerin olduğu nakledilmektedir. Bu düşünceye sahip olanlardan Zâhirîlik anlayışını ilk kez Endülüs'e getirip tanıtan Dâvûd b. Ali'nin talebesi Abdullah b. Muhammed b. Kâsım b. Hilâl (v. 272/885) ve Münzir b. Saîd el-Bellûtî'dir (v. 355/966). Zâhirîlik, İbn Hazm'a gelinceye kadar Endülüs'teki ilmî gelişimini ve silsilesini zayıf da olsa bir şekilde sürdürür. İbn Hazm ile birlikte Zâhirîlik düşüncesi Endülüs'te kuvvetli bir şekilde ortaya çıkar. Esas olarak Zâhirîlik anlayışını sistematik hale getiren, düşünce ve görüşlerinin sıhhatli bir şekilde bize kadar gelmesini sağlayan kişinin İbn Hazm olduğu bilinen bir gerçektir. Büyük bir ihtimalle belirli bir döneme kadar Mâlikî mezhebine mensup olan ve daha sonraları bazı siyasî nedenlerle kısa süreliğine Şâfiîliği benimseyen, mizacı gereği bu mezhepte de aradığını bulamayan İbn Hazm, sonradan Zâhirîliği benimser. İbn 
Hazm'ın bu değişim sürecinde bazı siyasî olayların ve ders aldığı Endülüslü Zâhirî âlimi, İbn Müflit'in önemli bir etkisinin olduğu nakledilmektedir. İbn Hazm yetiştirmiş olduğu öğrencilerin bazıları Endülüs'te, bazıları da Endülüs dışında Doğu'ya giderek Zâhirî düşüncesini yaymışlardır. İbn Hazm'dan sonra İbnü'l-Burhân'ın (v. 808/1405) Misır ve Şam'da Zâhirîliği yeniden diriltme uğraşlarından bahsedilmektedir. Fakat İbnü'l-Burhân bu çabasında başarılı olamamıştır. İbn Haldûn (ö. 808/1406) yaşadığı dönemde Zâhirîliğe mensup kimsenin kalmadığını mezhebin görüşlerinin de sadece kitaplarda yer aldığını aktarmıştır (Zehebî, 1417/1996: 18/184-200).

\section{3. İbn Abdülber'in Zâhirîleri Eleștirisi}

İbn Abdülber'in Zâhirilere yönelttiği eleştirileri iki ana başlıkta ele almamız ve incelememiz mümkündür. $\mathrm{Bu}$ başlıklardan biri usûl yönünden yapmış olduğu eleştiriler bir diğeri de füru' fikıh açısından yönelttiği eleştirilerdir.

\section{1. İbn Abdülber'in Zâhirîleri Usûl Yönünden Eleştirisi}

İbn Abdülber'in yönelttiği eleştirilerin bir kısmı Zâhirîlerin usûl düşüncesine yöneliktir. İbn Abdülber'in usûl yönünden Zâhirilere yönelttiği eleştirilerin temelinde de kıyas yer almaktadır. Usûlle ilgili eleştirilerin bir kısmını da bereât-i zimmet ve Zâhirîlerin temel kaidesi olan zâhire göre yorumda bulunmak düşüncesi oluşturmaktadır.

\subsubsection{Kıyas Delilini Reddetmelerine Yönelik Eleştirisi}

Şa‘bi (v. 104/722), İbrahim en-Nazzâm (v. 231/845), Mutezile'den Ca'fer b. Harb (v. 236/850), Cafer b. Mübeşşîr (v. 234/848), Muhammed b. Abdillah el-İskâfî (v. 240/854) ile ehl-i sünnetten Dâvud b. Alî ez-Zâhiri gibi birtakım âlimler (İbn Haldun, 1425/2004: 2/186) kıyasa karş1 çıkıp kıyas delilini kabul etmemişlerdir. Zâhirîlerden İbn Hazm, "Allah hüküm hususunda dinde hiçbir eksik mesele bırakmadan dini kemale erdirdiğinden, kim şer'i hükümlerin yeterli gelmediğini bu nedenle bilinmeyenlerin bilinenlere kıyas edilmesi gerektiğini iddia ederse bu da Allah'ın dinde ihmalde bulunduğu fikrini çağrıştırdığından dolayı küfre girebilir. Hâlbuki Allah "Bugün sizin için dininizi kemale erdirdim, size nimetimi tamamladım." (el-Mâide, 5/3) demekte ve din hususunda her şeyi açıklığa kavuşturduğunu, bir eksik bırakmadığını söylemektedir. Ayrıca İbn Hazm, kıyas işlemine başvuran âlimlerin aklı işlevsizleştirme hususunda Sofestailerden daha ileri gittiklerini iddia etmektedir (İbn Hazm, ts: 7/194). İbn Hazm'e göre hiçbir mesele birbirinin tıpa tıp aynısı olmayıp her bir mesele kendi özelinde farklı olduğundan birbirinden ayr1 değerlendirilmelidir. Dolayısıyla benzerlik sebebiyle bir meselenin hükmü bir başka meseleye verilemez. Her bir mesele müstakil ele alınmalıdır. Bu nedenle İbn Hazm'e göre kıyas yöntemi ikinci asırda icad edilmiş bir bidattir (İbn Hazm: 7/196-197).

İbn Abdülber, Dâvûd b. Ali'nin mezhebine mensup âlimlerin kıyasa karşı çıkarken dayandıkları delilleri de şu şekilde aktarmaktadır: Resulullah'tan (s.a.s) şöyle bir hadis rivayet edilmiştir: "Ümmetim yetmiş küsur gruba ayrılacaktır. Bu gruplar içinde ümmetime en fazla zarar verenler din hususunda re'yleri ile kıyas yapanlardır. Bunlar Allah'ın helal kıldığını haram, haram kıldığını da helal k1lmaktadırlar." (Taberânî, 1404/1983: 18/ 50-51).

İbn Abdülber, kıyas aleyhinde görüş ileri sürenlerin gerekçelerini aktardıktan sonra kıyası reddedenlere karşı kıyasın meşruluğu hususunu açıklamakta ve reddedenleri eleştirmektedir. İbn Abdülber, Zâhirîlerin kıyas yerine istidlal delilini savunduklarını ve kıyas yöntemini reddettiklerini söylemektedir. Ona göre aslında Dâvûd b. Ali'nin mezhebine mensup âlimlerin istidlal diye savundukları delil de bir çeşit kıyastır. Dolayısıyla kıyas için söz konusu olabilecek eleştirilerin istidlal içinde geçerli olabileceğini söyler. Ayrıca Peygamber'den (s.a.s) rivayet edildiği söylenen kıyas karşıtı hadisin de muhaddislere göre sahih olmadığı, Ahmed b. Hanbel (ö. 241/855) ve Yahya b. Main (ö. 233/848) gibi hadis otoriterlerinin bu hadisin aslının bulunmadığı yönünde görüş belirttiklerini aktarır. Ancak seleften gelen kıyasın kötülenmesiyle ilgili ifadeler de ya aslına uygun olmayan kıyas hakkındadır ya da kendisi ile aslî delilin reddedildiği kıyas hakkındadır (İbn Abdülber, 1994: 892-894.). İbn Abdülber'e göre kıyasın meşruluğu konusunda rivayet edilen Muâz hadisi hem sahih hem de meşhur bir hadistir. Zira bu hadisi güvenilir raviler nakletmiştir. İblis'in kıyas işlemine başvurduğundan yanıldığı hususuna cevap olarak da şu açıklamaları yapmaktadır: İblis, ilmin aslını (Allah'ın emrini) fasit bir görüşle reddetmiştir. Kıyası meşru görenlerin kabul ettikleri gibi fikhî kıyasta ise fürû aslına döndürülür, asıl re'y ve zanla reddedilmez. Kur'ân ve Sünnet'te nas mevcut olup, bu nastan çıkarılan hüküm de doğru bir şekilde ortaya konmuşsa, kıyas yoluyla hüküm koyma veya o konuda görüş beyan etme reddedilemez. Nitekim bu hususta Allah: "Allah ve Resûlü, bir işte hüküm verdiği zaman, inanmış bir erkek ve inanmış bir kadına o işi, kendi isteklerine göre seçme hakk1 yoktur." (el-Ahzâb, 33/36) buyurmuştur. Durum bu iken hangi delil Allah'ın İblis'e secde etmesi için verdiği emirden daha kuvvetli olabilir. Allah, Âdem'i ve İblis'i neden yarattığını en iyi bilendir. Sonra Allah, İblis'e Âdem'e secde etmesini emretti ve İblis de secde etmekten kaçındı ve Allah'ın dilediği şeyi İblis'e emretmesine engel teşkil etmeyecek bir nedenden dolayı İblis kibirlendi (el-Bakara, $2 / 34$ ). İblis'in bu ve benzeri yaptığı şeyler doğru bir kıyas değildir. Ancak asıllarına uygun bir şekilde yapılan kıyası ve bir şeyde bulunan hükmü ortak illet vasıtasıyla benzerlerine uygulamaya hiçbir selef âlimi karşı çıkmamıştır. Kendilerinden kıyas eleştirisi rivayet edilen âlimlerin her biri şüphesiz bir şekilde kıyas işlemini uygulamışlardır. İbn Abdülber'e göre kıyası, ancak cahil veya hüküm çıkarma metotlarında selefe karşı olan koyu cahiller reddedebilir (İbn Abdülber, 1994: 894-895).

\subsubsection{Bereât-i Zimmet ve Zâhire Aykırı Görüşlerine Yönelik Eleştiriler}

İbn Abdülber'e göre ticaret mallarından zekât alınmayacağı konusunda Dâvûd b. Ali ve arkadaşları ayrıca berâet-i zimmet yöntemine başvurmuşlardır. Onlar bu mesele hakkında Kitap, Sünnet'ten kesin bir nas ve âlimlerin icmâ' ${ }_{1}$ bulunmaksızın insanlar konuyla ilgili gerçekte olmayan bir şeyle yükümlü tutuluyorlarmış gibi hareket etmektedirler. İbn Abdülber, Zâhirîlerin bu konuda berâet-i zimmet kaidesine dayanmalarının şaşılacak bir şey olduğunu iddia eder. Ona göre bu yöntem, onların usûl anlayışıyla çelişmekte ve mezheplerini üzerine inşa ettiklerini iddia 
ettikleri Kur'ân ve Sünnet'in zahirine uygun yorum anlayışla da uyuşmamaktadır. Çünkü Allah (cc) Kur’ân'da “Onların mallarından zekât al." (et-Tevbe, 9/103) demekte ve malların hiç birini tahsis etmemektedir. Hâlbuki bu âyetin zahirine göre ümmetin icmâ'da bulunduğu zekât alınmayacak mallar dışındaki mallardan zekât alınması gerekirdi. Fakat ticaret mallarından zekât alınmayacağ hususunda da icmâ' mevcut değildir. Tam aksine fakihlerin cumhuru ticaret mallarında zekâtın cereyan edeceği hususunda görüş birliğine varmış ve bu görüşleri de hiçbir şekilde oraya buraya çekilecek cinsten ifadeler de değildir (İbn Abdülber, 1414/1993: 9/114).

\subsection{Füru` F1kıh Konularıyla İlgili Eleştirileri}

İbn Abdülber usûl kaideleri hususunda Zâhirîleri eleştirdiği gibi usûl konularından kaynaklı füru' konularda da onları eleştirmiştir. $\mathrm{Bu}$ eleştirilerinden bazıları kasten zamanında edâ edilmeyen namazların kazâsı, namazdan önce kamet getirmenin farz oluşu, Mushaf'a abdestsiz dokunabilme, faizin cereyan ettiği mallar, ticaret mallarının zekâtı vs. konularıdır. Makale sınırlarını aşmamak ve konuyu aydınlığa kavuşturmak amacıyla bunlardan sadece birkaçına değinilecektir.

\subsubsection{Zamanında Kasten Edâ Edilmeyen Namazın Kazâsı Hususundaki Eleştirisi}

Zâhirîlerden İbn Hazm'e göre uyuya kalan, unutan veyahut sarhoşken vaktinde namaz kılamayan kişiler ilgili âyet ve hadislere göre vakit çıktıktan sonra da namazlarını k1labilirler. Bunu söylerken de unutan veyahut uyuya kalan kimseler hakkında Peygamber'den (s.a.s) rivayet edilen "Uyuyan kişide ihmal yoktur. İhmal uyanık olan kişide bulunmaktadır. Sizden biri uyuya kalır ya da vaktinde namaz k1lmayı unutursa hatırladığı ve uyandığı vakit namazını kılsın.” hadisine dayanır. Sarhoş olan kimselerin ayıldıkları vakit namazlarını kılabilecekleri hususunda da "Siz sarhoş iken ne söylediğinizi bilinceye kadar, namaza yaklaşmayın." (en-Nisâ, 4/43) âyetini delil olarak getirir. Bunların dışında kalan ve kasten vaktinde namazı terk eden kimsenin daha sonra vaktin dışında namazı kazâ edemeyeceğini iddia eder. $\mathrm{Bu}$ iddiasını da "Vay haline o namaz kılanların ki, Onlar namazlarının özünden uzaktırlar." (el-Maûn, 107/4-5) ve "Sonra bunların ardından artık namazı kılmayan ve nefsânî arzulara uyan bir nesil geldi. Bunlar elbette azgınlıklarının cezasını bulacaklardır." (Meryem, 19/59) âyetlerine dayandırmaktadır. Ona göre şayet kasten namazı terk eden kişinin terk ettiği namazın kazâsı uygun olsaydı Allah bu kimselere azap vaat etmezdi. Azap vaat ettiğine göre bunlar kasten terk ettikleri namazı kazâ edemezler. İbn Hazm'a göre nasıl ki vakit girmeden namaz kılınamazsa vakit çıktıktan sonrada namaz kılınamaz. İbn Hazm, kasten vaktinde farz namazlarını kılmayanların telafi için tövbe ve istiğfarda bulunup, çokça iyilik yapması ve bolca nafile namaz kılması gerektiğini belirtmektedir (İbn Hazm, 2002/1425: 2/10).

İbn Abdülber'e göre Zâhirîlerin bir kısmı bu görüşleriyle cumhura (Şirbînî, 1418/1997: 1/198: İbn Abidin, 1423/2003: 2/518.) muhalefet edip şaz duruma düşmüşlerdir. Onların bu görüşlerini de bazı gerekçeleri zikrederek eleştirir. Onun ileri sürdüğü gerekçeleri şu başlıklar altında dile getirmek mümkündür:

\subsubsection{Peygamber'in (s.a.s) Uygulama ve Sözlerini Naklederek}

İbn Abdülber, bu konuda Zâhirîlerin kendileri dışındaki fakihlerin oluşturmuş olduğu icmâ'ya (Zâhirîlerin aykırı görüşlerinin icmâya zarar vermediğine dair bk. Eşit, 2019: 175-176) aykırı davrandıklarını söylemektedir. Ayrıca Hz. Peygamber'den rivayet edilen "Sizden kim akşam güneş batmadan ikindi vaktinin bir rekâtını kılarsa ikindi vaktine yetişmiştir/namazı vaktinde kılmıştır. Kim de sabah güneş doğmadan sabah namazının bir rekâtına yetişirse/kılarsa namazı vaktinde kılmıştır." hadisinde de vakti dışında namaz kılan kişinin, unutma ya da kasti kılmama diye bir özelliği belirtilmemiştir. Bütün fakihler bu şekilde nakilde bulunmuşlar ve onlara göre söz konusu vakitlerde namaz kılan kişi sabah ve ikindi namazını tam olarak vaktinde kılmış sayılır. Konuyla ilgili iyi bir araştırma yapan ve delillerden gerekli çıkarımlarda bulunarak derinlemesine düşünen kişiler, unutan kişiyle bilerek geciktiren kişinin bu konuda aynı durumda olduklarını anlar.

Bir diğer delilse ne Hz. Peygamber ve ne de sahâbe Hendek savaşının yapıldığı gün öğle ve ikindi namazlarının hiç birini güneş batıncaya dek kılamamışlardır. Hz. Peygamber öğle ve ikindi namazlarını ancak gece olduktan sonra kılabilmiştir. Hâlbuki Hz. Peygamber namazlarını unuttuğundan veya uyuduğundan dolayı tehir etmemiş ve sıcak çatışma ortamı da oluşmamıştı.

Sünnet'ten bir diğer örnek de Hz. Peygamber, Hendek savaşından hemen sonra Beni Kureyzâ Yahudilerine karşı gönderdiği sahâbelere "Beni Kureyzâ topraklarına varıncaya kadar kimse ikindi namazını kılmasın.” buyurmuştur. Bir kısım sahâbe bu emrin zahirine uyup oraya varıncaya kadar ikindi namazını kılmamışlardı. Beni Kureyzâ topraklarına vardıklarında akşam olmuş ikindi namazlarını da ancak akşam vaktinden sonra kılabilmişlerdi. Bu olay/durum $\mathrm{Hz}$. Peygamber'e ulaşınca Hz. Peygamber hiçbirini kınamamış onları azarlamamıştır. Hâlbuki ikindi namazını vaktinde kılmayıp akşam girdikten sonra kılanların hiçbiri unuttuklarından veyahut uyuduklarından dolayı namazlarını vakit çıktıktan sonra kılmamışlardır. Hz. Peygamber bu durumu bildiği halde kimseye bir namaz ancak vaktinde kılınır, vakti çıktıktan sonra kılınamaz ya da kazâ edilemez diye bir şey söylememiştir.

Sünnet'ten bir diğer delil de Hz. Peygamber'in "Benden sonra namazları vaktinden sonraya tehir edecek yöneticiler gelecektir. Sahâbeler: Onlara uyup onlarla beraber namaz kılalım mi? diye sorunca. Hz. Peygamber 'evet kılın' dedi." $\mathrm{Bu}$ rivayette Hz. Peygamber vaktinden sonraya tehir edilip kılınan namaz için 'vaktinde kılınmayan namaz kılınamaz veya kazâ edilemez’ dememiştir (İbn Abdülber, 1414/1993: 1/303-304).

\subsubsection{Genel Kaide, İşlenen Günahtan Tövbe Etmek}

Bilerek vaktinde namaz kılmayan kişinin günahkâr/asi olacağı hususunda âlimler görüş birliğine varmışlardır. Bazı âlimler vaktinde bilerek namaz kılmamanın büyük günahlardan biri olduğunu iddia etmekte ise de cumhura göre kebâirden sayılmamaktadır. Yine âlimler Allah'ın emrine asi olanların yaptıklarından pişmanlık duyup bir daha aynı fiili ihmal etmeyeceklerine karar vermeleri gerektiğ yönünde icmâ'da bulunmuşlardır. Bu âlimlerin dayanağı "Ey Müminler! Hepiniz Allah'a tövbe edin, umulur ki 
kurtuluşa erersiniz.” (en-Nûr, 24/31) âyetidir. Kimin üzerinde Allah'ın veya bir kulun hakkı bulunursa gereğini yaparak bu haktan kurtulması gerekir.

İbn Abdülber, vaktinde kasten namazını kılmayan kişinin daha sonra yaptıklarından pişmanlık duyup namazını kazâ edebileceği hususunda oluşan icmâ'ya Zâhirîlerin aykırı hareket ettiğini söylemektedir. Ona göre Zâhirîler bu görüşüyle kendilerini ve kendi mezhep âlimlerinin de dayandığı usûle aykırı davranmaktadırlar. Âlimlere göre farziyeti hususunda icmâ' oluşmuş bir husus ancak onun düzeyinde oluşmuş bir icmâc, sıhhati hususunda tartışma bulunmayan sabit bir Sünnetle ancak düşürülebilir/sakıt edilebilir. Farz namazlar da icmâ' edilen hususlardandır. Dolayısıyla farziyetinin düşürülmesi bir icmâ‘ veya sabit, sahih ve tartışmasız kabul edilen bir Sünnetle olabilir.

İbn Abdülber'e göre Peygamber (s.a.s) vaktinde kılınamayan namazın telafisi/kazâsı hususunda uykuda kalıp zamanında uyanamayan ya da unutan kimseleri zikredip başka sebeplerle namazı edâ etmeyenleri zikretmemesinin sebebi ise bu kişilerin belirtilen durumlarından dolayı günahkâr olmamalarıdır. Peygamber'e (s.a.s) göre bu kişilerin günahkâr duruma düşmemeleri onlardan namaz sorumluluğunu kaldırmaz, bu nedenle uyandıklarında veyahut hatırladıklarında namaz vakitleri çıkmış olsa da kaçırdıkları namazı kazâ etmeleri kendilerinden istenmiştir (İbn Abdülber, 1414/1993: 1/306-307).

\subsubsection{Kasten Terk Edilen Namazın Vakti Dışında Kazâ Edilmesini Ramazan Ayında Tutulamayan Oruca Kıyasta Bulunarak Gerekçelendirmesi}

İbn Abdülber'e göre Allah, vaktinde yerine getirilememeleri halinde kazâ edilmeleri hususunda oruçla namaz ibadetini bir tutmuştur. Zikredildiği gibi $\mathrm{Hz}$. Peygamber namaz hususunda uyuya kalanla unutan kişiyi zikrettiği gibi oruç hususunda da Allah Kur'ân'da yolcu ve hastayı zikretmiştir. Orucun farziyetine iman ettiği halde bilerek zamanında oruç tutmayan kişi daha sonra bu günahından/yanlışından dolayı tövbe ederse bu kişinin Ramazan ayında tutmadığı oruçları kazâ etmesi hususunda Ümmet icmâ‘ etmiş ve bunu nakletmişlerdir. Namazı bilerek zamanında kılmayan kişinin tövbe ettikten sonra kazâ etmesi gerektiği hususu da aynı şekildedir. Zira günah açısından durumları farklı olsa da namaz ve orucun kazâsı hususunda bilerek ya da unutarak kılmayanların durumları birdir. Bu mesele başkasının malına bilerek veya bilmeyerek zarar veren kişinin durumuna benzer. Namaz ve oruç her ikisi de farz, yerine getirilmeleri zorunlu bir sorumluluktur. Her ne kadar zaman geçse de ifa edilmeleri gereken birer sabit borçturlar. Konuyla ilgili Peygamber (s.a.s) "Yerine getirilme yönünden öncelikli borç Allah'ın hakkıdır." demektedir (İbn Abdülber, 1414/1993: 1/301).

\subsubsection{Aklî Deliller Getirerek Gerekçelendirmesi}

Uyuya kalan veya unutan kişiler mazur oldukları halde vaktinde kılamadıkları namazları kazâ etmeleri gerekmektedir. $\mathrm{Bu}$ nedenle kasten terk ettiğinden dolayı günahkâr olan şahsın sorumluluğu düşmediğinden namaz borcunu kazâ etmesi daha önceliklidir ve bu nedenle kılmadığı namazları kazâ etmesine hükmedilir. Çünkü namazın kasten terkinin tövbesi, zamanında görevini yapmadığından dolayı pişmanlık duyması ve yerine getirmediği sorumluluğu ifa etmesiyle olur (İbn Abdülber, 1414/1993: 1/301).

\subsubsection{Zâhirî Bazı Fakihlerin Namazla İlgi Temel Görüşlerini Aktararak Gerekçelendirmesi}

İbn Abdülber, kasten namazı terk eden kişinin sonradan namazı kazâ edemeyeceği görüşünün Zâhirîlerin namaz konusuyla ilgili bazı temel anlayışlarına ters düştüğünü iddia eder. Namazla ilgili Zâhirîlerin iki temel anlayışını iki Zâhirî fakihten aktaran İbn Abdülber, vaktinde kasten namazı terk eden kişinin bu görüşlere göre namazlarını kazâ edebileceğini söyler. Görüşlerini dayanak olarak aktardığı Zâhirî fakihlerden biri Ebû Hasan b. Muğallistir. Ebû Hasan b. Muğallis'in “el-Muvaddih alâ mezhebi ehli'z-Zâhir" adlı eserinde konuyla ilgili şu temel görüşlerini aktarmaktadır: "Eğer bir kişi bir bostanda/bahçede, necis bir mekanda ya da bir yere bağlı bulunsa ve abdest alma imkanı bulamazsa o kimse üzerine abdest alabilinceye kadar namaz kılma sorumluluğu/yükümlülüğü yoktur. Abdest alabilme imkânını elde ettiği herhangi bir vakitte teyemmüm veya abdest alarak namazını kılar." İbn Abdülber'e göre bu kişi uyuya kalmadığı ve de namazı unutmadığı halde bu Zâhirî fakihe göre bu kişi vakti çıkan namazlarını kılabileceğini söylemektedir. Ayrıca İbn Abdülber bu konuda Zâhirîler arasında görüş ayrılığının bulunduğu yönünde herhangi bir rivayet olmadığını da ileri sürmektedir.

Bir diğer Zâhirî fakih Ebû Abdullah Ahmed b. Muhammed ed-Dâvudî el-Bağdâdî'nin görüşlerini de kitabı "Câmiu mezhebi ebî Süleyman"dan aktarmaktadır. Bu fakih kitabının "Taharet bölümünün hayızlının namazı ve orucu" başlığında şunları söylemektedir: "Vakti çıkmadan daha temizken kılmadığı namazı daha sonra adete/hayza giren bayanın iade etmesi gerekir. Şayet bayan vakit çıkıncaya kadar namazını kılmaz ve adet göreceği vakte kadar namaz kılmadan oyalanırsa bu kılamadığı namazının aynısını temizlendiğinde k1lar." Bunları aktardıktan son İbn Abdülber şunları belirtmektedir: "Selef ve halef bütün fakihlerin vaktinde bilerek terk edilen namazın sonradan kazâ edilebileceğiyle ilgili ittifak ettikleri görüşlerine muhalefet eden kişi âlim sınıfına giremez ve ilmî bir meselede şaz bir görüşle hareket eden öncü bir fakih sayılamaz." (İbn Abdülber, 1414/1993: 1/309).

\subsubsection{Mushaf'a Abdestsiz Dokunabilme Görüşlerine İlişkin Eleş̧tirileri}

İbn Abdülber'in Zâhirîlere eleştiri yönelttiği meselelerden biri de Mushaf'a abdestsiz dokunabilme ve cünüpken Kur'ân okuyabilme meselesidir. Zâhirîlere göre Mushaf'a dokunabilmek için abdestli olmaya gerek yok hatta hayızlı veyahut cünüplü bir kişi de ona dokunabilir. Ayrıca Kur'ân okuyabilmek ve tilavet secdesi yapabilmek için abdestli olmak gerekmez. Aynı şekilde hayızlı ve cünüp kişi de bunları yapabilir. Zâhirîler bu görüşlerini şu şekilde gerekçelendirirler. Kur'ân okumak, tilavet secdesi yapmak, zikirde bulunmak mendup olup, yapanın mükâfatlandırılacağı hayır işlerdendir. Bunların abdestli yapılması gerektiği yönde görüş ileri sürenlerin delil ileri sürmeleri/getirmeleri gerekir. Ayrıca Kur'ân'ın abdestli okunması görüşünde olanlara karşı abdestsiz okunabileceğiyle ilgili görüşler bizim görüşümüzü desteklemektedir. Ömer b. Hattab, Ali b. Ebî Talib (r.a) gibi sahâbelerden ve Hasan el-Basrî, Katâde ve Nehaî gibi 
tâbiînlerden hayızlı ve cünüp kişinin okuyamayacağı görüşü aktarılmıştır. Cünüplünün Kur'ân'ı okuyamayacağı görüşü, Ali b. Ebî Talib'in aktardığı “'Hz. Peygamber'i cenabetlik dışında hiçbir şey Kur'ân okumaktan alıkoymazdı." sözüne dayandırılmaktadır. Hâlbuki bu sözde onların lehine bir ifade yer almamaktadır. Zâhirîler nakledilen bu sözü, hoşlanmazdı veya yapmamıştır anlamına yorumlar ve bu sözün yasak ifadesini barındırmadığını ileri sürerler. Mushaf’a abdestsiz dokunulmayacağıyla ilgi rivayet edilen hadisi de mürsel ve hadisin geçtiği belirtilen yazılı sahifenin meçhul ya da zayıf olduğunu bu nedenle bunlarla ihticac edilemeyeceğini iddia ederler. Bir diğer dayanakları/gerekçeleri ise $\mathrm{Hz}$. Peygamber'in Bizans Kralı Herakli'ye göndermiş olduğu mektuptur. Onlara göre bu mektupta Ali İmrân suresi 3/64. âyeti yazılı olduğu halde gönderilmiş ve okuyup ona dokunan Bizanslıların abdestli olmadıkları ileri sürülmüştür. el-Vâkıa suresinde yer alan "Ona ancak temiz olanlar dokunabilir." (el-Vâkı, 56/79) âyetinin de haber kipiyle geldiğini ve yasak ifade etmediğini iddia etmektedirler. Bu örneklerden yola çıkarak insanlardan abdestli olanlarla olmayanların hepsinin Kur'ân'a dokunabildiği, kimsenin onları engellemediğini ayrıca âyette geçen temiz olanlardan kastın da melekler olduğunu ifade etmektedirler (İbn Hazm, 2002/1425: 1/94-99). Zâhirîlere göre "Mümin necis değildir." hadisi gereği Müslümanlar temiz sayılacağından hayızlı ve cünüpken de Mushaf'a dokunabilirler (İbn Abdülber, 1414/1993: 8/13).

İbn Abdülber Zâhirîlerin konuyla ilgili ileri sürdükleri gerekçeleri şu şekilde eleştirmektedir: Birincisi konuyla ilgili rivayet edilen "Mushaf'a ancak abdestli olanlar dokunabilir." hadisi bazı tariklerden her ne kadar mürsel olarak gelmişse de başka kanallardan muttasıl olarak da nakledilmiş sahih bir hadistir. İster ehil-i re'y olsun ister ehili hadis olsun nerdeyse bütün fakihlerce kabul görmüş bir hadistir. $\mathrm{Bu}$ hadise dayanarak Hanefî, Mâlikî, Şâfî̂ ve Hanbelî fakihler abdestsiz Mushaf'a dokunulamayacağı yönünde görüş birliğine varmışlardır. Hatta Hakem b. Uteybe (v. ö. 115/733), Hammâd b. Süleyman (v. 120/738) gibi bu konuda şaz kalan birkaç kişi dikkate alınmasa konuyla ilgi icmâ‘ oluşmuştur da denebilir (İbn Abdülber, 1414/1993: 8/12; Serahsî, 3/152, 195; Şirbînî, 1/64, 71).

İkincisi bu konuda delil olarak kullanılan âyet her ne kadar haber kipinde gelmişse de emir manası taşımaktadır. Zira bunun örnekleri Arap dilinde ve Kur'ân'da çokça bulunmaktadır (İbn Abdülber, 1414/1993: 8/12). Mushaf'a abdestsiz dokunulabileceğiyle ilgili görüşe gelince bu görüşü ileri süren İmam Mâlik gibi fakihler Mushaf başka eşyalarla birlikte bir kolide yer alır ve de sadece Mushaf'1 taşıma kastıyla değil de bütün eşyaları taşıma kastıyla dokunulursa uygun olur demişlerdir (İbn Abdülber, 1414/1993: 8/11). Âyette geçen "temiz olanlar" ifadesi, ilgili hadisle beraber değerlendirildiğinde Mushaf’a dokunabilmek için abdestli olmaya bir işaret olduğunu söylemek mümkündür. Çünkü burada "temiz olma" özelliği vurgulanarak, müminler işaret yoluyla da olsa uyarılmakta ve mümkün mertebe Mushaf'a abdestli dokunulması tavsiye edilmektedir.

\subsubsection{Faizin Cereyan Ettiği Mallarla İlgili Görüşlerine Yönelik Eleştirileri}

Fakihlerin faizle ilgili tespitlerinin dayanağı ve hareket noktası, Ubâde b. Sâmit'in "Altına karşılık altın, gümüşe karşılık gümüş, buğdaya karşılık buğday, arpaya karşılık arpa, hurmaya karşı1lı hurma, tuza karşılık tuz cinsi cinsine birbirine eşit ve peşin olarak satılır. Malların sınıfları değişirse peşin olmak şartıyla istediğiniz gibi satın" (Müslim, 1210; Tirmizî, 1388/1968: 3/533) rivayet ettiği bu hadisin yanı sıra bazı önemsiz kelime farklılıklarıyla Ebû Hüreyre ve Ebû Saîd el-Hudrî gibi sahâbelerin rivayet ettiği ve nerdeyse bütün sahih hadis kaynaklarında yer alan rivayetlerdir (Buhârî, 760; Müslim, 1209-1210). Bu hadislerde Hz. Peygamber altın, gümüş, buğday, arpa, hurma ve tuzun birbiriyle değiş tokuşunda hangi durumlarda faizin oluşabileceğini açıklamıştır. Bu nedenle belirtilen altı eşyada faizin gerçekleşeceği ittifakla kabul edilmiştir. Fakat fakihler, hadislerde geçen altı maddenin o günün şartlarında en çok işlem gören maddeler olduğu ve hadiste zikredilmeyen diğer mallar için kıstas olabilecek özellikler taşıyıp taşımadığı ve faizin sadece bahsedilen altı maddenin değişiminde mi oluşabileceği konusunda ihtilaf etmişlerdir. Yukarıda ifade edildiği gibi kıyas işlemini bir delil olarak kabul etmeyen Zâhirîlerle kıyas işlemini delil olarak kabul edip de yalnız bu konuda kıyasa başvurmayan Osman elBettî'ye (v. 143/760) göre faiz sadece bu altı maddenin veresiye veya peşin değişiminde gerçekleşir. Ehl-i sünnet mezheplerinin de içinde yer aldığı fakihlerin çoğunluğuna göre ise faiz bu altı maddeyle sinırlı olmayıp benzer özelliklere sahip başka mallarda da cereyan eder (Serahsî, ts: 12/112).

Zâhirîlerden İbn Hazm'e göre alış-veriş ve selem işlemlerinde faiz sadece hurma, buğday, arpa, tuz, altın ve gümüşte gerçekleşir. Bu altı maddenin dışındaki başka maddelerde gerçekleşmez. Bunun gerekçelerini belirtirken de faizle ilgili âyetleri zikreder ve faize düşmemek için faizle ilgili gerekli bilgilere sahip olunması gerektiğini söyler. Onlara göre faizle ilgili naslarda sadece bu altı mal zikredildiğinden faiz sadece bunlarda gerçekleşir. İbn Hazm, ayrıca Tâvus, Katâde, Osman el-Bettî ile Ebû Süleyman ve bütün Zâhirîlerin faizin bu altı maddede gerçekleştiği yönünde görüş belirttiklerini aktarır. Ona göre insanlar bu konuda ihtilaf etmiş bazısı "Bu altı madde bir ölçü ve örnek olsun ve benzerlerine de kıyas yoluyla aynı kural uygulansın diye zikredilmiştir." demektedir. Bu şekilde görüş belirtenler de illetin ne olması gerekeceği hususunda ihtilaf etmişlerdir. Kimisi illetin "tartılabilirlik” özelliği olduğunu iddia ederken kimisi "g1da maddesi" ve "depolanabilirlik" özelliklerinin kimisi "yiyecek olma" özelliğinin kimi de "zekâta tabi olma" özelliğinin olduğunu söylemiş dolayısıyla ortak bir illet belirleyememişlerdir. Ona göre bu görüşlerin hepsi delilden yoksun, uygun olmayan görüşlerdir. Ayrıca bu altı maddenin kıyas yoluyla benzerlerine uygulanacağı görüşü için icmâ‘ bulunduğunu söylemek doğru değildir. Belki de sekiz on sahâbenin benimsediği bir görüştür. İbn Hazm, Hz. Peygamberden rivayet edilen "Yiyecekler yiyecekler karşılığında mübadele edildiğinde aynı miktarda olmaları gerekir." "Yiyecekler ancak misli misline/eşit olarak satılabilir." hadislerinin uydurma olduklarını ileri sürmektedir. Ayrıca bu rivayetler doğru kabul edilse de yiyecek maddesi ifadesi Arapçada buğday için kullanılmakta ve bazen de yemekler için de kullanılmaktadır (İbn Hazm, 2002/1425: 7/401).

İbn Abdülber'e göre sahâbeden, tabiinden ve onlardan sonra gelen fakihler Ubâde b. Sâmit ve diğer sahâbelerden nakledilen benzer hadisler gereğince faizin zikredilen hadislerde geçen altı şeyde cereyan ettiği hususunda ittifak etmişlerdir. Kıyas işlemini yöntem olarak kabul eden 
fakihler bu hadislerde zikredilen altı maddeye benzer özelliklerinden dolayı pirinç, mısır, mercimek vs. gibi maddeleri dâhil etmişlerdir. Hadiste zikredilen altı maddede oluşan faiz işleminin benzer maddeler için de geçerli olduğunu söylemişlerdir. $\mathrm{Bu}$ konuda Katâde ve kıyas işlemini geçerli görmeyen Dâvûd b. Ali onlara muhalif olmuşlar ve hadiste zikredilen altı maddenin dışında başka maddeler için nesê ve tefâdul faizinin gerçekleşmediğini iddia etmişlerdir. İbn Abdülber, Zâhirîlerin bu görüşlerini faizle ilgili rivayet edilen altı şeyi zikreden rivayetle "Allah alış verişi helal kıldı.” (el-Bakara, 2/275) âyetine dayandırdıklarını söylemektedir. Bunun sonucu olarak da bu altı maddenin dışında nesîe ve tefâdul "fazlalık faizi" (ribe'lfadl) faizinin gerçekleşmeyeceğini savunmuşlardır. İbn Abdülber bu görüşlerinden dolayı Zâhirîlerin ve onlar gibi düşünenlerin şaz kaldıklarını ve cumhura muhalefet ettiklerini söylemektedir (İbn Abdülber, 1414/1993: 20/41).

\subsubsection{Ticaret Mallarının Zekâtı Meselesinde Zâhirîleri Eleştirisi}

İbn Hazm'a göre sekiz sınıf malın dışında zekât sorumluluğu bulunmamaktadır. Bu sekiz sınıf da altın, gümüş, buğday, arpa, hurma, deve, sığır ve koyundur. Bu sekiz sınıf maldan zekât verilmesi gerektiği hususunda görüş birliği bulunmaktadır (İbn Abdülber, 1414/1993: 9/112; İbn Hazm, 1425/2002: 4/12). Bunların dişındaki malların zekâtı hususunda ise ihtilaf edilmiştir. Ona göre sayılanların dışında ticaret malları, meyve, ziraî ürünler, maden, at ve balda zekât yoktur. İbn Hazm bu sekiz sınıfın dışında diğer fakihlerce zekâta tabi kabul edilen mallar hususunda delil olarak nakledilen rivayetleri bir takım eleştirilere tabi tutmakta, görüşleriyle uyumlu olmayanların bir kısmını zayif veya uydurma olarak nitelendirmektedir. Sahih olanların ifadelerini de te'vil yoluna giderek görüşlerini desteklemeye çalışmaktadır. Örneğin Hz. Peygamber'in ticaret yapanların bilerek veyahut bilmeyerek mallarına karışan meşru olmayan mallara kefaret olması için miktar/ölçü belirtmeden onlardan sadaka vermelerini istemiştir diyerek rivayetleri görüşüne uygun bir şekilde yorumlamaktadır (İbn Hazm, 1425/2002: 4/41). İbn Hazm bu konuda özellikle "Beş veskten az olan hububat ve hurmada zekât yoktur." rivayetine dayanmakta ve hadiste geçen 'hab' ifadesini de arpa ve buğday için kullanıldığını söyleyerek hububattan bu ikisinden zekât verileceğini iddia etmektedir. Ayrıca altın ve gümüş dışında para olarak kullanılan maddelerin ve madenlerin zekâta tabi olmadığını söylemektedir. Sahâbeden gelen örnekler için de sadaka olarak verildiklerini, zekât niyetiyle verilmediklerini ileri sürmektedir (İbn Hazm, 1425/2002: 4/12-40).

İbn Abdülber, ticaret mallarının zekâtı hususunda Zâhirîlerin şaz duruma düştüklerini, fakihlerin cemaatine muhalefet ederek, ister alındığında ticarete niyet edilsin ister edilmesin ticaret mallarının zekâta tabi olmadıklarını iddia ettiklerini nakletmektedir. Zâhirîler bunu söylerken 'Müslüman'ın atı ve kölesi hususunda/üzerine zekât sorumluluğu yoktur." hadisine dayanmaktadırlar. Onlar ticaret malları hususunda fakihler arasında ihtilaf olduğu zehabına kapılmış ve hadislerin umum ifade edenlerini delil olarak kullanmışlardır. Ayrıca Aişe, Abdullah b. Abbas, Ata ve Amr b. Dinar'ın "Malların zekâtı yoktur." dediklerini iddia etmektedirler.
İbn Abdülber adı geçen fakihlerden ve onların dışındaki bazı âlimlerden "Malların zekâtı yoktur." "Altın, tarım ürünleri ve hayvanlar dişında zekât yoktur." benzer ifadelerin aktarıldığını söylemektedir. Bu rivayetlerde geçen "mallar" ifadesinin, ticaret maksadı dışında edinilen mallara yönelik olduğunu belirtmektedir. Ticaret mallarının zekâtı ancak satılıp paraya çevrildikten sonra verileceği hususunda İbn Abbas dışında da kimseden de böyle bir görüş aktarılmamıştır. Dâvûd b. Ali'nin delil olarak bir diğer dayanağı da İmam Mâlik'in "Mal mübadelesinde bulunan tüccarın malını paraya dönüştürmedikçe ve ticaret için mal alan kişi mallarını satıp para elde etmedikçe zekât vermeleri gerekmez.” sözüdür. İbn Abdülber'e göre İmam Mâlik'in bu ifadesinde onun lehine bir ifade bulunmamaktadır. Zira İmam Mâlik ticaret malı paraya dönüştürüldüğünde paranın senesi beklenmeden malın zekâtının verilmesi gerektiğini söylemektedir. Dolayısıyla bu söz onun lehine değil aleyhinedir. Ona göre Dâvûd b. Ali ne İmam Mâlik'in ne de başka bir fakihin bu konudaki sözlerini kale almaktadır. Bu nakillerle ancak mugalâta yapmaktadır (İbn Abdülber, 1414/1993: 9/114). Aynı durumu İbn Hazm'da da görmek mümkündür. Nitekim İbn Hazm fakihlerin aralarındaki bazı ihtilafları gerekçe göstererek onların zekâtla ilgili görüşlerini çürütmeye çalışmaktadır.

İbn Abdülber'e göre bu konuda Dâvûd b. Ali ve arkadaşları ayrıca berâet-i zimmet kaidesine başvurmaktadırlar. Onlar bu mesele hakkında ihtilaf varmış ve hakkında Kitap, Sünnet'ten kesin bir nas ve icmâ' bulunmadan insanlar bir şeyle yükümlü tutuluyorlarmış gibi görüş ileri sürmektedirler. İbn Abdülber, Zâhirîlerin bu konuda berâeti zimmet kaidesine dayanmalarının şaşılacak bir şey olduğunu iddia etmektedir. Ona göre bu yöntem onların usûl anlayışıyla çelişmekte ve mezheplerini üzerine inşa ettiklerini iddia ettikleri Kur'ân ve Sünnet'in zahirine uygun anlayışla/hareketle uyuşmamaktadır. Çünkü Allah Kur'ân'da “Onların mallarından zekât al.” (et-Tevbe, 9/103) demekte ve malların hiçbirini tahsis etmemektedir. Bu âyetin zahirine göre zekât alınmayacak mallar hususunda ümmetin icmâ‘da bulunduğu için söz konusu malların dışındakilerden zekât alınması gerekirdi. Hâlbuki ticaret mallarından zekât alınmayacağı hususunda da icmâ' mevcut değildir. Tam aksine fakihlerin cumhuru ticaret mallarında zekâtın cereyan edeceği hususunda görüş birliğine varmış ve bu görüşleri de hiçbir şekilde oraya buraya çekilecek cinsten ifadeler de değildir (İbn Abdülber, 1414/1993: 9/114; Serahsî: 2/190; Şirbînî: 1/587; Makdisî, ts: 1/443).

Zâhirîlere karşı Sünnet'ten getirilen delile gelince; bunlar lehlerine ileri sürdükleri iki hadistir. Birincisi "Müslüman'ın atı ve kölesi hususunda/üzerine zekât sorumluluğu yoktur." rivayetidir. Diğeri ise Ali'nin (r.a) naklettiği "Sizi atlarınızın ve kölelerinizin zekâtından muaf tutuyorum." hadisidir. Aslında bu iki rivayetin zahirine göre Zâhirîlerin bu iki mal (yani köle ve at) dışındaki malların zekâta tabi olduklarını kabul etmeleri gerekirdi. İbn Abdülber, Zâhirîlerin kıyas işlemini kabul etmediklerinden at ve köle dışındaki malları bu ikisine kıyas edip bunlara zekât düşmez görüşünü ileri sürmemeleri gerektiğini söyler. Ayrıca ticaret mallarının zekâta tabi olmadıkları hususunda icmâ'nın bulunmaması hasebiyle ticaret mallarının zekâta tabi olmadıklarını iddia etmemeleri gerektiğini ifade eder. İbn Abdülber bu delillerin dışında ticaret mallarının zekâta tabi oldukları hususunda Hz. Peygamber'in, sahâbe ve tâbiînden fakih olanların sözlerini aktarır (İbn Abdülber, 1414/1993: 9/112-115). 
Bunlardan biri Hz. Peygamber'den Semure b. Cündeb tarafindan hasen bir senetle rivayet edilen "Hz. Peygamber ticaret için bulundurduğumuz malların zekâtını vermemizi emrederdi." hadisidir. Bir diğer rivayette de Ömer'in (r.a) uygulaması aktarılmaktadır. Bu rivayette Hammas şöyle demektedir: "Bir gün omuzumun üzerinde taşıdığım bir miktar deri bulunduğu halde Ömer'in yanından geçerken, ey Hammas! Bunun zekâtını ödeyesin ha. Ben de ey Müminlerin Emiri benim bu tabaklanmış derilerden başka malım yoktur. Ömer de bunlar maldır ve yere koy/bırak. Onları onun önüne bıraktım. O da söz konusu derilerin değerini hesaplayıp zekât nisabına ulaştığını görünce onların zekâtını aldı." İbn Abdülber, konuyla ilgili benzer birçok rivayet aktardıktan sonra Abdullah b. Ömer'in (r.a) konuyla ilgili "Ticaret için ayrılan her mal, köle ve hayvanda zekât vardır." sözünü nakleder. İbn Abdülber, uygulamalarla ilgili Tahâvî’nin “Ömer ve Abdullah b. Ömer'den (r.a) diğer sahâbelerin muhalefet etmediği benzer söz ve uygulamalar gelmiştir." dediğini aktarır. Abdullah b. Ömer'in (r.a) "Ticaret için ayrılan her köle, hayvan ve gıda maddesi zekâta tabidir." Sünnet'e dayanmadan bu sözü kişisel bir görüş olarak söylemesi mümkün gözükmemektedir. İbn Abdülber, Dâvûd b. Ali'nin Atâ ve Amr b. Dinâr'dan naklettiği sözleri yanlış aktardığını iddia etmekte ve bu kişilerden rivayet edilen görüşlerden farklı görüşlerin nakledildiğini ileri sürmektedir. Ona göre tâbiîn fakihlerinden Said b. Müseyyeb, Kasım b. Muhammed, Urve b. Zübeyir, diğer yedi fakih, Hasan el-Basrî, İbrahim en-Nehâ̂, Tavus elYemânî, Cabir b. Zeyd ve Meymûn b. Mihrân gibi âlimlerden ticaret mallarının zekâta tabi oldukları yönünde sözler nakledilmektedir (İbn Abdülber, 1414/1993: 9/115118).

\subsection{Değerlendirme}

İbn Abdülber'in yorumlarında da görüldüğü gibi Zâhirîler kıyas anlayıșı hususunda kendilerini savunmak adına mugalâta yapma yoluna gittikleri anlaşılmaktadır. Nitekim Zâhirîler seleften, ehil olmayanlar tarafindan yapılan ve yanlış uygulanan kıyas örneklerine yönelik eleştirileri naklederek kıyasa karşı oluşlarını gerekçelendirme yoluna gitmişlerdir. Nitekim çoğu zaman İbn Hazm, herhangi bir ekolün görüşünü çürütmek için bir başka ekolün delillerini kullanmakta ve en sonunda da bu ekol eleştirildiği gerekçesiyle onların da görüşlerini reddetmektedir. Hatta ilim sahibi kimseler tarafından sahih görülen hadisleri bazı tariklerindeki zayıflık nedeniyle amel edilemez diye reddetmişlerdir. Hâlbuki Mushaf'a abdestsiz dokunma meselesinde olduğu gibi konuyla ilgili hadisin başka yollarla sahih bir şekilde rivayet edildiği görülmektedir. Zekâta tabi olan mallar meselesinde ifade edildiği gibi konuyla ilgili âyetin zâhirî delaletine itibar etmeyip kendi zâhirî anlayışlarının dışına çıktıkları da anlaşılmaktadır. Bunun sebebi de bazı meselelerle ilgili delilleri lokal/parçacı olarak ele almaları ve kuşatıcı, genel bir değerlendirme yoluna gitmemeleri olduğu söylenebilir.

İslam Hukukunun temel dayanakları/delilleri ve bu delillerden hüküm çıkarma yöntemlerinin büyük önem arz ettiği, bu nedenle nasları gereği gibi değerlendirip sınırlı sayıdaki nasların hükümlerini sistemli bir şekilde genişleterek oluşan sorunlara tutarlı çözümler üretebilme başarısının fikıh ekollerinin günümüze kadar yaşamasına olanak sağladığını söylemek herhalde abartılı olmayacaktır. Nitekim cumhuru fukâhanın gerekli gördüğü ve usûl anlayışında büyük bir öneme haiz kıyas anlayışını reddeden Zâhirîler bu anlayışlarından kaynaklı birçok konuda cumhurla çeliştiklerinden halk nezdinde itibar görmemiş ve belirli bir dönemden sonra sadece kitaplarda yer alan kültürel ve ilmî miras olarak kalmışlardır. Bunların yanı sıra sağlıklı ve doğru bir usûl anlayışı fakihi yanlışa düşmekten koruyacağı gibi ona bu usûlle varılmış sonuçları savunma ve açıklama imkânı da verecektir.

Zâhirîler kıyas yöntemine karşı olmaları hasebiyle birçok meselede cumhura muhalefet etmişlerdir. Nitekim zamanında kasten kılınmayan namazın kazâsı, Mushaf’a abdestsiz dokunabilme, zekâta tabi mallar ve faizin cereyan ettiği mallar konularında da görüldüğü gibi Müslümanların çoğunluğuna ters düşmüşlerdir. $\mathrm{Bu}$ da bize cumhur fakihlerin fikhî görüşlerini temellendirmek için sağlıklı ve doğru bir usûl anlayışı oluşturdukları ve bunun sayesinde sistematik bir şekilde hareket ettiklerini göstermektedir. Ayrıca inşa ettikleri metot sayesinde sistemde oluşabilecek kaçaklara engel olmayı çalıştıkları da söylenebilir. Dolayısıyla İslam hukuku alanında çalışma yapacak kimselerin iyi bir delil bilgisi ve usûl altyapısının olması gerekir ki çalışmalarında çelişkiye düşmesin.

\section{Sonuç}

Yapılan araştırma sonucunda birçok meselede fakihlerin dayandıkları usûl anlayışından kaynaklı birçok yorum farklılığının olduğu görülmüştür. Bunun bir örneği olarak İbn Abdülber, sahip olduğu fikhî donanım gereği yaşadığı döneme kadar gelen fikıh mirasını değerlendirmeye tabi tuttuğu ve çağdaşı olan âlimlerin görüşlerini ele alıp yorumladığı anlaşılmıştır. Bunu yaparken de belirli bir usûl ve yöntem takip etmiştir. Geçmiş fikıh mirasına yönelik yapmış olduğu değerlendirme ve eleştirilerin bir benzerini Zâhirîlere yönelik de yapmıştır. İbn Abdülber bu eleştirileri yaparken de kendinden önce yaşamış olan fakihlerin fikıh mirasından olabildiğince yararlandığı anlaşıldığından iyi bir fakih olabilmek için nasların detaylı bilgisine hâkim olmak ve iyi bir usûl altyapısına dayanmak gerektiğinin farkına varılmıştır. Nitekim İbn Abdülber, kıyas anlayışını kabul etmeyen Zâhirileri bu tutumlarından dolayı eleştirirken ve onların bu konuda takip ettikleri yöntemlerin doğru olmadığını açıklarken bu geniş formasyona dayanmıştır. Ayrıca Zâhirîler kıyas işlemine uymadıklarından dolayı cumhurun görüşleriyle uyuşmayan birçok farklı hükme vardıkları zekâta tabi mallar meselesinde olduğu gibi bereâti zimmet delilini yanlış kullandıkları ve zâhirî anlayışlarına ters hareket ettikleri tespit edilmiştir. Bunun yanı sıra İbn Abdülber'in Zâhirîlere yönelik söz konusu eleştirileri yaparken de ilmî üslup ve edepten ayrılmadığı, kişilerden ziyade görüşlerle meşgul olduğu görülmüştür. Dolayısıyla günümüzde fikıh çalışmalarında bulunacak araştırmacıların başarılı ve görüşlerinde tutarlı olabilmeleri için geçmiş hukuk mirasını özümsemeleri gerektiğinin önemli olduğu anlaşılmıştır.

\section{Kaynakça}

Buhârî, A. (1418/1997). Keşfü'l-esrâr an usûli Fahri'lÍslam el-Pezdevî. 1. bs. Beyrut: Dâru Kutubi'l-İlmiyye. 
Apaydın, H. Y. (2013). "Zâhiriye”, Türkiye Diyanet Vakfı İslam Ansiklopedisi. İstanbul: TDV Yayınlar1, 44/93100.

Buhârî, M. (1407/1987). el-Câmi'u's-sahîh. (Mustafa Dîb Buğa thk.). Beyrut: Dâru İbn Kesir.

Câsim, L. (1999). "İbn Abdülber", Türkiye Diyanet Vakfi İslam Ansiklopedisi. İstanbul: TDV Yayınları, 19/269272.

Câsim, L. (1988). İbn Abdülber el-Endelüsî ve cühûduh fi'ttârîh. 2. bs. Kahire: Dâru'l-Vefa.

Cessâs, A. (1992/1412). Ahkâmü'l-Kur'ân. Beyrut: Dâru İhyâi't-Türâsi'l-Arabî.

Eşit, Y. (2019). "F1kıh Usûlünde İcmâ Ehliyeti Tartışmaları", Çukurova Üniversitesi İlahiyat Fakültesi Dergisi. 19(1), 168-184. DOI: 10.30627/cuilah.554730.

Humeydî, M. (2008). Cezvetü'l-muktebes fî târîhi 'ulemâi'lEndelüs. 1. bs. Beşşar 'Avvâd M'aruf- Muhammed Beşşâr 'Avvâd thk.). Tunus: Dâru'l-Ğarbi'l-İslamiyyî.

İbn Abdülber, Ö. (ts). el-İstî̀ âb fì m 'arifeti'l-ashâb.

İbn Abdülber, Ö. (1994). Câmi'u beyani'l-'ilm ve fadlihi. 1. bs. Riyad: Dâru İbni'l-Cevzî.

İbn Abdülber, Ö. (1414/1993). el-İstizkâr el-câmi' li mezâhibi fukâhai'l-emsâr ve 'ulemai'l-aktâr fîmâ tadammenehu'l-Muvatta min me'âni'r r'eyi ve'l-âsar ve şerhi zâlike kullih bi'l-icâz ve'ihtisâr. 1. bs. Haleb-elKahire: Dâru'l-V'ayi.

İbn Abdülber, Ö. (1967). et-Temhîd limâ fi'l-Muvatta mine'l-m'eâni ve'l-esânîd. (Mustafa b. Ahmed el-'Allevi ve Muhammed Abdulkebir el-Bekrî thk.).

İbn Abidin, M. (1423/2003). Reddü'l-muhtâr alâ dürrü'lmuhtâr. Riyad: Dâru Alemi'l-Kütub.

İbn Ferhûn, İ. (ts). el-Dîbâcu'l-müzheb fî m 'arifeti 'ayâni 'ulemai'l-mezheb.

İbn Haldun, V. (1425/2004). Mukaddime. 1. bs. Dımaşk: Dâru'l-Belhî.

İbn Hazm, A. (ts). el-İhkâm fî usûli'l-ahkâm. (Ahmed Muhammed Şâkir thk.). Beyrut: Dâru'l-Afâkı'l-Cedîde.

İbn Hazm, A. (2002/1425). el-Muhallâ bi'l-âsâr. Beyrut: Dâru Kütubi’l-‘ilmiyye,.

İbn Kesîr, İ. (2010). el-Bidâye ve'nihâye. 2. bs. (Memûn Muhammded Saîd es-Sâğırcî thk.). Dımaşk-Beyrut: Dâru İbn Kesîr.

Karadağ, B. (2020). Misır Hanefîliği (Memlükler Dönemi Hanefî Fıkıh Düşüncesi). Ankara: Astana yayınları.
Mâlik b. Enes.( 1406/1985). Muvatta '. (Muhammed Mustafa 'Azamî thk.). Abu Dabi.

Mahlûf, M. (2003). Şeceretü'n-nûru'z-zekiyye fì tabakâti'lMâlikiye. 1. bs. Beyrut: Dâru'l-Kutubi'l-'İlmiye.

Makdisî, Ş. (ts). el-íknâ'. el-Memleketu'l-'Arabiyyetu'sSudiyye.

Müslim, H. (ts). el-Câmiu's-sahîh. (Muhammed Fuâd Abdulbaki nşr.). Beyrut: Dâru İhyâu't-Türâsi'l-'Arabî.

Müzenî, İ. (1419/1998). Muhtasaru’l-Müzenî. Beyrut: Dâru Kütubi'l-'İlmiyye.

Nesâî, A. (ts). Sünenü'n-Nesâ̂̂, (Ebû 'Ubeyde Meşhûr b. Hasan âl Selmân nşr.). Riyad: Mektebetu'l-Me'arif.

Sallabî, Ü. (2011). İhtiyârâtu'l-Hâfiz İbn Abdülber elKurtubî fî fikhi'l-mü'amelat min kitabeyhi et-Temhîd ve'l-İstizkâr ve tatbikâtun mu'âsıretun. 1. bs. Beyrut: Dâru İbn Hazm.

Serahsî, Ş. (ts). el-Mebsût. Beyrut: Dâru'l-Ma'rife.

Sübkî, T. (ts). Tekmiletü'l-mecmû şerhi mühezzeb. Medine: el-Mektebetü's-Selefiyye.

Şafîi, M. (ts). el-Ümm. Riyad: Beytü'l-Efkâri'd-Devle.

Sercânî, R. (ts). Kissetu'l-Endelüs mine'l-fethi ile's-sukût.

Şenteriyyî, A. (1997). ez-Zahire fî mehâsini ehli’l-cezîre. (İhsan Abbas thk.). Beyrut: Dâru's-Sekâfeti.

Şeybânî, M. (ts). Kitâbu'l-hucce alâ ehli'l-Medine. Beyrut: Âlemu'l-Kutub.

Şirâzi, C. (ts). Tabâkatu'l-fukâha. Beyrut: Dâru Râidi'lArabiy.

Şirbînî, M. (1997/ 1418). Muğni'l-muhtâc ilâ marifeti meâni’l-elfâz. Beyrut: Dâru'l-Ma'rife.

Taberânî, S. (1404/1983). Kahire: Mu 'cemu'l-kebîr. (Hamdî Abdülmecid es-Selefî thk.).Mektebu İbn Teymiyye.

Teftâzânî, S. (1428/2007). Şerhu'l-'akâidu'n-Nesefiyye. 1. bs. Dâru'l-Beyrûtî.

Tirmizî, M. (1388/1968). Sünen. 2. bs. (Muhammed Fuad Abdulbaki thk.). Mektebetu Mustafa.

Zehebî, Ş. (ts). Kitâbu tezkiretü'l-hüffâz. Beyrut: Dâru'lKutubi'l-'İlmiyye.

Zehebî, Ş. (1417/1996). Siyeru alâmu'l-nübelâ, 11. bs. Beyrut, Müessetü'r-Risâle. 


\section{Extended Abstract}

From the first periods of Islamic history, there are various examples of criticism among Muslim ulema regarding different subjects and concepts. In fiqh sources, it is seen that many fuqaha criticized the views of fuqaha of their own madhhabs as well as the views of different madhhabs and their members. Among the schools of fiqh pointed out by these criticisms, differences based on interpretation are encountered in many issues of the ilm of fiqh. Since this situation varies according to the geography where the fuqaha lived, their fiqhi skills and their methods of evaluating the issue, different solution offers and evaluations have emerged. While trying to find solutions to new issues that arise in the field of Islamic law today, it is important to determine the methods the past ulema based upon in evaluating the fiqhi issues and to know the efforts they made to reach a sahih fiqhi solution. In this context, the criticism of Ibn Abd al-Barr (d. 463/1071), who is accepted as one of the outstanding ulema of the XIth century, of the Zāhirīs is important. Determination of the issues in the focus of these criticisms and their usuli bases will be based on the works written by Ibn Abd al-Barr, the sources of the Zāhirīs and the studies done on the subject.

We can easily say that Ibn Abd al-Barr is a faqih from the Mālikī school, since he used the adillah and methods on which the Mālikī fuqeha based upon, while making ahkam from the nusus or while making fiqhi choices. His being a member of the Mālikī madhhab does not mean that he accepts all the views of the madhhab without questioning. When his works are examined, it is evidently seen that he criticizes the opinion that does not comply with the understanding of usool he follows or the fiqhi principles he obeys, to whomever it belongs, and clearly supports the correct view according to his own fiqhi qawaeid. As a matter of fact, while dealing with the issue of wudu, after examining the pros and cons of the adillah in the Mālikī madhhab regarding whether wudu will be broken by touching a foreign woman or not, he does not approve the view of the fuqeha of the Malikî madhhab that just because of the feeling of shahwa arising by touching a woman who can be married while there is a thin veil in between the wudu will be invalidated. In the section where he deals with Witr prayer, he cites a lot of evidence regarding the issue in order to clarify a number of issues. According to the Shafii madhhab, it is fard to perform salawat in tashahhud and after tahiyyat while performing prayers. Ibn Abd al-Barr, who disagrees with this view of the Shafiis, discusses the issue in detail under the title of evidences on the subject of salawat to the Messenger of Allah. After evaluating the evidence, he criticizes Imam Shafii, who says that salawat is fard in the final tasahhut: "The main thing is that the fards are determined by the ijma' that there is no evidence or opposition to it. The opinion of Imam Shafii and his friends on this issue is weak. I do not see it compulsory to say salawat to the Prophet in every prayer; but I do not find it nice to leave salawat. " It is possible to say that Ibn Abd alBarr discussed and evaluated the criticisms directed to the Zâhirīs under two main headings. One of these titles is the criticisms he has made in terms of method and the other one is the criticisms he has made in terms of füru'al fiqh. Some of the criticisms made by Ibn Abd al-Barr are directed towards the procedural idea of the the Zāhirīs. There is also a comparison on the basis of Ibn Abd al-Barr's criticism of the Zāhirīs in terms of method. Some of the criticisms about the method are formed by the thought of evaluating according to the basic rule of bereât-i embezzlement and the Zāhirīs. Ibn Abd al-Barr criticized the Zāhirīs in terms of procedural rules and also criticized them in fürü issues arising from procedural issues. Some of these criticisms are the accident of the prayers that are not performed deliberately on time, the obligatory to bring the prayer before the prayer, the ability to touch the Mushaf without ablution, the goods on which the interest occurs, the zakat on trade goods, etc. are subjects. Ibn Abd al-Barr says that the Zāhirīs acted contrary to the ijma created by the jurists other than themselves, regarding the methods used by the Prophet in conveying his words and practices. In addition, It is narrated from the Prophet that "Whoever of you performs one rak'ah of the afternoon before the sun sets in the evening has reached the afternoon time / performed the prayer on time. And whoever performs one rak'ah of the morning prayer before the sun rises in the morning, he performed the prayer on time. " In the hadith, it is not stated that a person who performs prayers outside of his time, such as forgetting or not performing intentions. All the jurists were reported in this way and according to them, the person who prayed at these times is considered to have performed the morning and afternoon prayers exactly on time. People who do a good research on the subject and reflect on the evidence by making the necessary inferences can easily understand this and understand that the person who forgets and the person who deliberately delayed is in the same situation. Ibn Abd al-Barr says that the Zāhirīs act contrary to the consensus that a person who does not perform his prayers deliberately at the time may regret what he did later and perform his prayer. According to him, with this view, the Zāhirīs behave contrary to the methodology of themselves and their own sect scholars. According to the jurists, an issue that has been formed in terms of fardship can only be abrogated / canceled by a fixed Sunnah that is formed at the level of it. Fard prayers are also among the issues that are concluded. Therefore, the reduction of the fardship can be through an ijma $\mathrm{S}$ or a Sunnah that is accepted as fixed, sound and indisputable. As it can be seen in the evaluations of Ibn Abdulbar, it is seen that the Zāhirīs chose to make mjâta in order to defend themselves regarding the understanding of comparison. Zāhirīs justified their opposition to the comparison by conveying the criticisms conveyed by Salaf scholars about the examples of comparison made by the incompetent and misapplied. In fact, they rejected the hadiths that were regarded as sound by those who had knowledge because they could not be deeded due to the weakness of some of their tarik. However, as in the issue of touching the Mushaf without ablution, it is seen that the hadith regarding the issue is authentically narrated in other ways. As we have seen in the issue of goods subject to zakat, it is understood that they disregard the apparent manifestation of the verse on the subject and go beyond their apparent understanding. It can be said that the reason for this is that they dealt with the evidence on some issues locally and they did not use an encompassing and general assessment. 